\title{
Cation channels trigger apoptotic death of erythrocytes
}

\author{
KS Lang ${ }^{1}$, C Duranton ${ }^{1}$, H Poehlmann ${ }^{1}$, S Myssina ${ }^{1}$, C Bauer ${ }^{2}$, \\ F Lang ${ }^{\star,}$, T Wieder $^{1}$ and SM Huber ${ }^{1}$ \\ ${ }^{1}$ Department of Physiology, University of Tübingen, D-72076 Tübingen, \\ Germany \\ 2 Department of Physiology, University of Zürich, Zürich, Switzerland \\ * Corresponding author: Florian Lang, Physiologisches Institut, Universität \\ Tübingen, Gmelinstr. 5, D-72076 Tübingen, Germany, \\ Tel: +49 707129 72194; Fax: +49 707129 5618; \\ E-mail: florian.lang@uni.tuebingen.de
}

Received 4.4.02; revised 23.7.02; accepted 12.9.02

Edited by $T$ Cotter

\begin{abstract}
Erythrocytes are devoid of mitochondria and nuclei and were considered unable to undergo apoptosis. As shown recently, however, the $\mathrm{Ca}^{2+}$-ionophore ionomycin triggers breakdown of phosphatidylserine asymmetry (leading to annexin binding), membrane blebbing and shrinkage of erythrocytes, features typical for apoptosis in nucleated cells. In the present study, the effects of osmotic shrinkage and oxidative stress, well-known triggers of apoptosis in nucleated cells, were studied. Exposure to $850 \mathrm{mOsm}$ for $24 \mathrm{~h}$, to tert-butylhydroperoxide $(1 \mathrm{mM})$ for $15 \mathrm{~min}$, or to glucose-free medium for $48 \mathrm{~h}$, all elicit erythrocyte shrinkage and annexin binding, both sequelae being blunted by removal of extracellular $\mathrm{Ca}^{2+}$ and mimicked by ionomycin $(1 \mu \mathrm{M})$. Osmotic shrinkage and oxidative stress activate $\mathrm{Ca}^{2+}$-permeable cation channels and increase cytosolic $\mathrm{Ca}^{2+}$ concentration. The channels are inhibited by amiloride $(1 \mathrm{mM})$, which further blunts annexin binding following osmotic shock, oxidative stress and glucose depletion. In conclusion, osmotic and oxidative stress open $\mathrm{Ca}^{2+}$-permeable cation channels in erythrocytes, thus increasing cytosolic $\mathrm{Ca}^{2+}$ activity and triggering erythrocyte apoptosis.

Cell Death and Differentiation (2003) 10, 249-256. doi:10.1038/ sj.cdd. 4401144
\end{abstract}

Keywords: cell volume; Annexin; osmotic cell shrinkage; oxidation; tert-butyl-hydroperoxide; glucose depletion; calcium

Abbreviations: $\mathrm{tBOOH}$, Tert-butyl-hydroperoxide

\section{Introduction}

Similar to other cell types, erythrocytes have to be eliminated after their physiological life span. ${ }^{1}$ Beyond this, mechanisms are required for the removal of defective erythrocytes. In other cell types, the primary mechanism of clearance is apoptosis. ${ }^{2,3}$ Until very recently, erythrocytes have been considered unable to undergo apoptosis, as they lack mitochondria and nuclei, key organelles in the apoptotic machinery of other cells. ${ }^{1}$ However, most recent observations revealed that treatment of erythrocytes with the $\mathrm{Ca}^{2+}$-ionophore ionomycin leads to cell shrinkage, cell membrane blebbing and annexin binding, all typical features of apoptosis in other cell types. ${ }^{1,4,5}$

The present study has been performed to test whether erythrocyte annexin binding could be induced by osmotic shock or oxidative stress, well-known triggers of apoptotic death of other cell types. ${ }^{6-12}$ It is indeed shown that both challenges lead to annexin binding. Further experiments have been done to elucidate the cellular mechanisms involved. It is shown that the effect of osmotic shock and oxidative stress is dependent on the presence of $\mathrm{Ca}^{2+}$ and mimicked by stimulation of $\mathrm{Ca}^{2+}$ entry with ionomycin, that osmotic shock and oxidative stress, both, open $\mathrm{Ca}^{2+}$-permeable cation channels and increase cytosolic $\mathrm{Ca}^{2+}$ concentration, and that amiloride, an inhibitor of the cation channels, blunts the stimulation of annexin binding following osmotic shock or oxidative stress.

\section{Results}

\section{Osmotic shock and oxidative stress activate a calcium-permeable cation channel}

Whole-cell recordings of untreated erythrocytes show a low conductance in the range of $0.1-2 \mathrm{nS}$, reflecting the low resting channel activity within the erythrocyte cell membrane (Figure 1). As shown in Figure 1a and c, both, osmotic cell shrinkage by addition of sucrose and oxidative stress by addition of $1 \mathrm{mM}$ of the oxidant tert-butyl-hydroperoxide $(\mathrm{tBOOH})$ decrease the erythrocyte cell membrane resistance. Figure $1 \mathrm{~b}$ illustrates the $\mathrm{I} / \mathrm{V}$ relation of the activated current after cell shrinkage. In additional experiments, the channel characteristics were defined. Figure $1 \mathrm{~d}$ and e reveal the $\mathrm{Ca}^{2+}$ conducting property of the channel. The channel is inhibited by high concentrations (1 mM) of amiloride (Figure 1F). From these results, we conclude that osmotic and/or oxidative shock activate a calcium-permeable cation channel in the erythrocyte cell membrane.

\section{Osmotic shock, oxidative stress and glucose depletion increase cytosolic calcium content}

In untreated erythrocytes the total cellular $\mathrm{Ca}^{2+}$ content $\left[\mathrm{Ca}_{\mathrm{T}}\right]_{\mathrm{i}}$ was approximately $2 \mu \mathrm{mol} / 10^{13}$ cells at an extracellular $\mathrm{Ca}^{2+}$ concentration of $150 \mu \mathrm{M}$ (Figure 2). Addition of the $\mathrm{Ca}^{2+}$ ionophore ionomycin $(1 \mu \mathrm{M})$ led to a rapid and sustained increase of cellular $\left[\mathrm{Ca}_{\mathrm{T}}\right]_{\mathrm{i}}$ (Figure $2 \mathrm{a}$ ). Increase of the extracellular osmolarity to $850 \mathrm{mOsm}$ led within $30 \mathrm{~min}$ to a doubling of $\left[\mathrm{Ca}_{T}\right]_{i}$ (Figure $2 \mathrm{~b}$ ). A similar increase of $[\mathrm{Ca} T]_{i}$ 


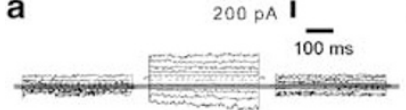

isotonic hypertonic isotonic

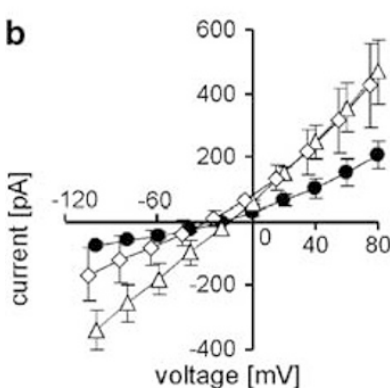

c

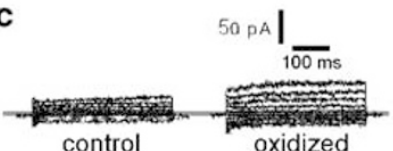

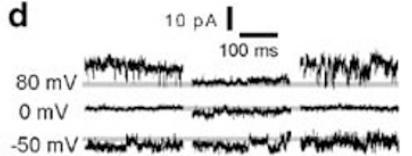

$\mathrm{Na}^{+} \mathrm{NMDG}^{+} \mathrm{Ca} 2+$

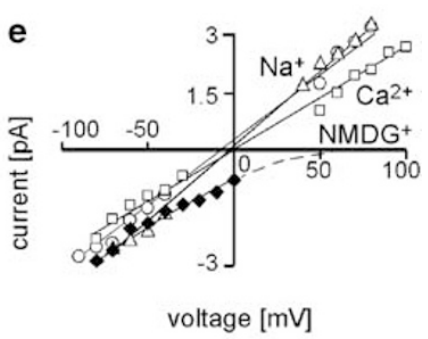

f

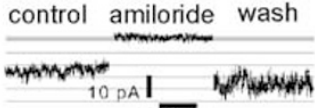

Figure 1 Cell-shrinkage- and oxidative stress-induced nonselective cation channels in human erythrocytes. (a) Original whole-cell current traces (Kgluconate/ $\mathrm{KCl}$ pipette solution) recorded with isotonic bath solution, after addition of $400 \mathrm{mM}$ sucrose to the bath solution (hypertonic), and after wash-out of sucrose by isotonic bath solution. The zero current is indicated by the grey line. (b) Current-voltage relationships recorded as in (a) with isotonic (closed circles) and hypertonic $\mathrm{NaCl}$ bath solution $(+400 \mathrm{mM}$ sucrose; open triangles) and after replacement of $\mathrm{NaCl}$ by NMDG-Cl (+400 mM sucrose, open diamonds). Data are means \pm S.E.M.; $n=3$. (c) Original whole-cell current traces $(\mathrm{NaCl}$ pipette solution) recorded with isotonic $\mathrm{NaCl}$ bath solution, before (left) and after applying oxidative stress ( $1 \mathrm{mM} t$-BOOH for $10 \mathrm{~min}$ ). (d) Single channel current transitions recorded in the excised-patch, inside-out mode at various voltages with $\mathrm{KC}$ pipette and Na-gluconate $\left(\mathrm{Na}^{+}\right)$, NMDG-gluconate $\left(\mathrm{NMDG}^{+}\right)$, and $\mathrm{Ca}$-(gluconate $)_{2}$ bath solution $\left(\mathrm{Ca}^{2+}\right)$, respectively. The closed state of the channels is indicated by grey lines. (e) Current-voltage relationships as recorded in (d) with $\mathrm{Na}^{+}$(open circles and triangles), $\mathrm{Ca}^{2+}$ (open squares), and $\mathrm{NMDG}^{+}$(closed diamonds) as principal cation in the bath solution. (f) Original current tracings of an outside-out patch recorded at $-100 \mathrm{mV}$ voltage $(\mathrm{KCl}$ pipette and $\mathrm{Na}$ gluconate bath solution before (control), during (amiloride) and after (wash-out) applying amiloride in the bath solution. Thick grey line indicates zero current

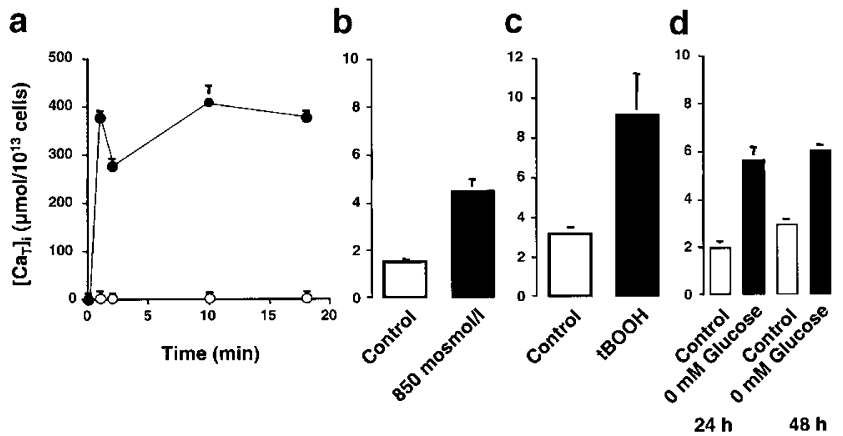

Figure 2 Increase of intracellular $\mathrm{Ca}^{2+}$ content $\left[\mathrm{Ca}_{\mathrm{T}}\right]_{i}$ following exposure to ionomycin, osmotic shock, oxidative stress or glucose depletion. Arithmetic means \pm S.E.M. $(n=3)$ of intracellular $\mathrm{Ca}^{2+}$ content $\left[\mathrm{Ca}_{\mathrm{T}}\right]$; following exposure of erythrocytes to $1 \mu \mathrm{M}$ ionomycin (a, closed symbols), to osmotic shock (b, $850 \mathrm{mOsm}$ buffer for $30 \mathrm{~min}$ ), oxidative stress (c, $1 \mathrm{mM}$ tBOOH for $10 \mathrm{~min}$ ) or to glucose depletion for $24 \mathrm{~h}$ or $48 \mathrm{~h}$ (d). Controls (open symbols in a, open columns in $\mathbf{b}$-d) indicate respective values in the absence of ionomycin, osmotic shock, oxidative stress and presence of $5 \mathrm{mM}$ glucose. Values of $\left[\mathrm{Ca}_{\mathrm{T}}\right]_{\mathrm{i}}$ are given as $\mu \mathrm{mol} / 10^{13}$ cells

was observed following a $10 \mathrm{~min}$ exposure to $1 \mathrm{mM} \mathrm{tBOOH}$ (Figure 2c) and a 24 or $48 \mathrm{~h}$ exposure to glucose-free buffer (Figure 2d).

\section{Increase of cytosolic calcium by ionomycin induces erythrocyte apoptosis}

In order to test the hypothesis that stress-induced opening of calcium-permeable channels in the erythrocyte membrane leads to activation of the apoptotic programme in this cell type, we used the calcium-ionophore ionomycin. As shown in the scatter plots in Figure $3 \mathrm{a}$, the addition of $1 \mu \mathrm{M}$ ionomycin led within $3 \mathrm{~h}$ to marked calcium-dependent cell shrinkage. A decrease of forward scatter from a value of $428 \pm 13(n=3)$ in control cells to $121 \pm 2(n=4)$ in ionomycin-treated cells was observed. Moreover, exposure of erythrocytes to $1 \mu \mathrm{M}$
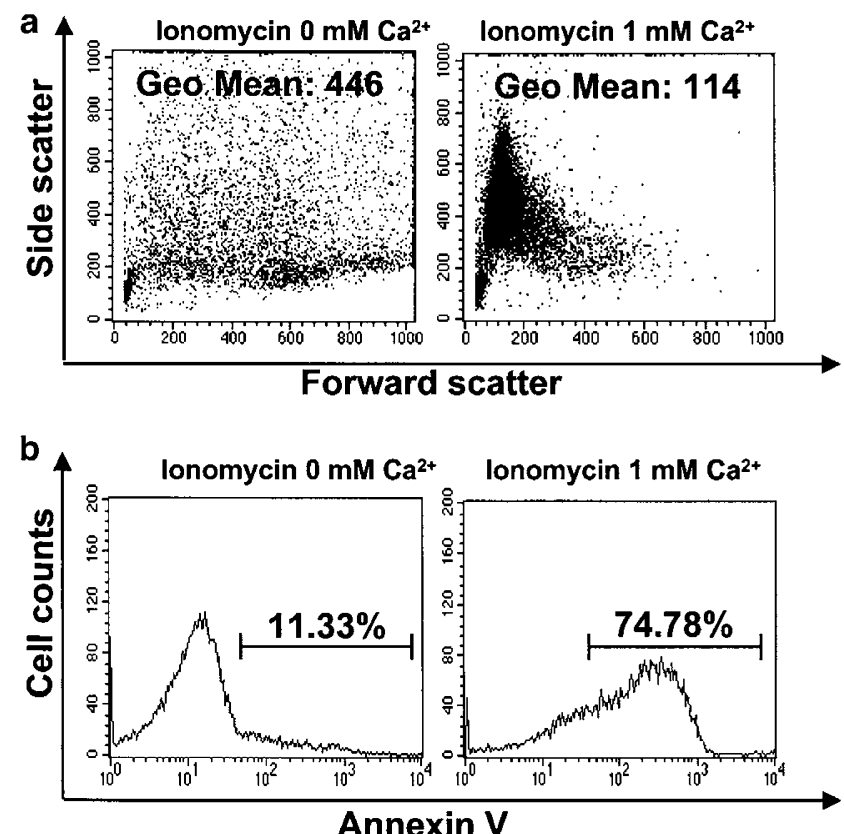

Annexin V
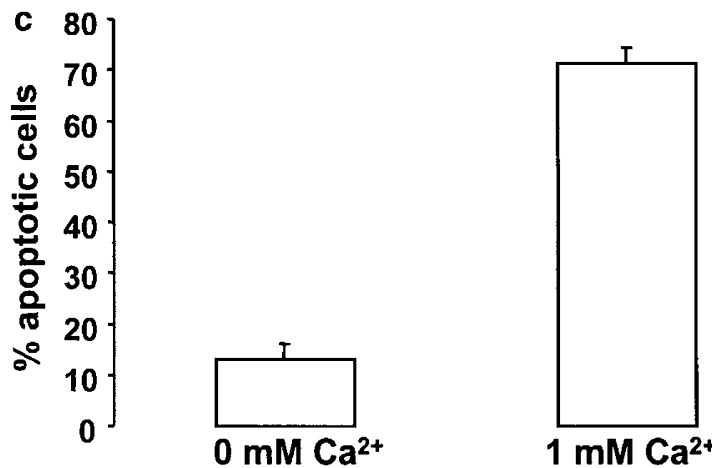

Figure 3 lonomycin induced erythrocyte apoptosis. (a) Effects of $1 \mu \mathrm{M}$ ionomycin after $3 \mathrm{~h}$ of incubation on cell volume without $\mathrm{Ca}^{2+}$ (left panel) and with $\mathrm{Ca}^{2+}$ (right panel) in the extracellular solution as evidenced from forward scatter analysis. Geometric mean values are given for a single experiment. (b) Phosphatidylserine asymmetry after $3 \mathrm{~h}$ of ionomycin treatment, as evidenced from annexin binding without $\mathrm{Ca}^{2+}$ (left panel) and with $\mathrm{Ca}^{2+}$ (right panel) in the extracellular solution (c). Arithmetic means ( + S.E.M.) of annexin binding in cells exposed to $1 \mu \mathrm{M}$ ionomycin for $3 \mathrm{~h}$ without and with $\mathrm{Ca}^{2+}$ in the extracellular fluid 
ionomycin enhanced the annexin binding from $4.1 \pm 0.4 \%$ $(n=3)$ in control cells to $71.3 \pm 3.2 \%(n=4)$ in ionomycintreated cells. A typical experiment is shown in Figure $3 b$. lonomycin-induced cell shrinkage and annexin binding are both significantly blunted in the nominal absence of extracellular calcium (Figure $3 a, b)$. The respective values were $337 \pm 16(n=4)$ for the forward scatter and $12.9 \pm 3.1 \%(n=4)$ for the annexin binding (Figure $3 c$ ). Thus, treatment of erythrocytes with ionomycin elicits two effects typical for apoptosis, i.e, phosphatidylserine exposure and cell shrinkage.

\section{Osmotic shock induces erythrocyte annexin binding}

Osmotic shock has been shown to induce apoptosis in different nucleated cell types. ${ }^{6,8-12}$ To test for triggering of apoptotic cell shrinkage and annexin binding, cells were exposed to osmotic shock (preincubation in $850 \mathrm{mOsm}$ by addition of sucrose for $24 \mathrm{~h}$ ). Following this incubation, the cells were incubated in isotonic solution for 20 min containing the fluorescent annexin and measured in the FACS Calibur for forward scatter, side scatter and annexin binding. Following this procedure the cells remained slightly shrunken (Figure $4 a)$, as reflected by a decrease of the forward scatter from $421 \pm 25(n=5)$ to $336 \pm 20(n=5)$. Removal of extracellular $\mathrm{Ca}^{2+}$ did not blunt cell shrinkage $(327 \pm 21, n=3)$. In the presence of amiloride $(1 \mathrm{mM})$ cell volume approached $378 \pm 11(n=3)$.

Osmotic shock also increased annexin binding (Figure 4bd). Exposure to $850 \mathrm{mOsm} / \mathrm{l}$ led to an increase of annexinbinding cells from $3.9 \pm 0.3 \%(n=4)$ to $51.4 \pm 3.8 \%(n=9)$ within $24 \mathrm{~h}$. A typical experiment is depicted in Figure $4 \mathrm{~b}$. In the nominal absence of calcium, the effect of osmotic shock
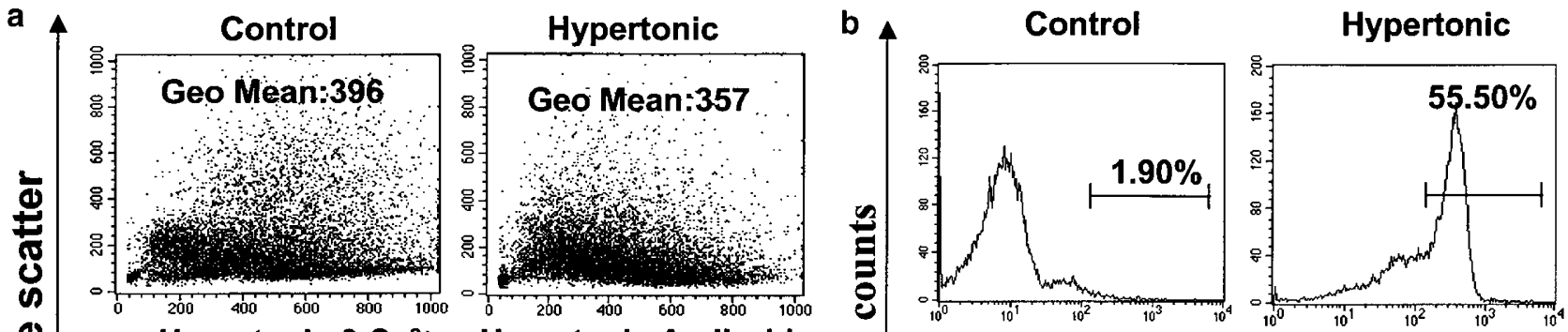

Hypertonic $\mathbf{0} \mathrm{Ca}^{2+}$
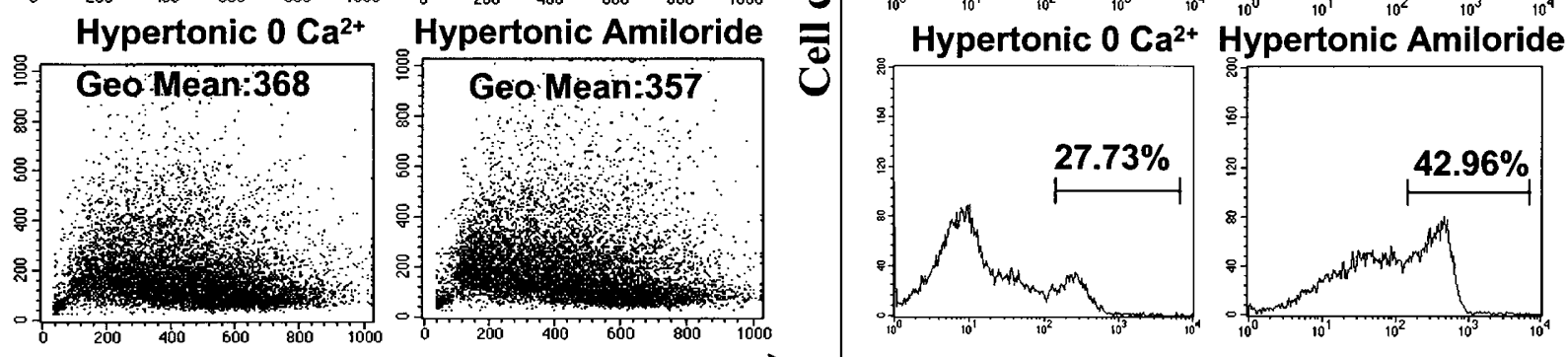

Forward scatter

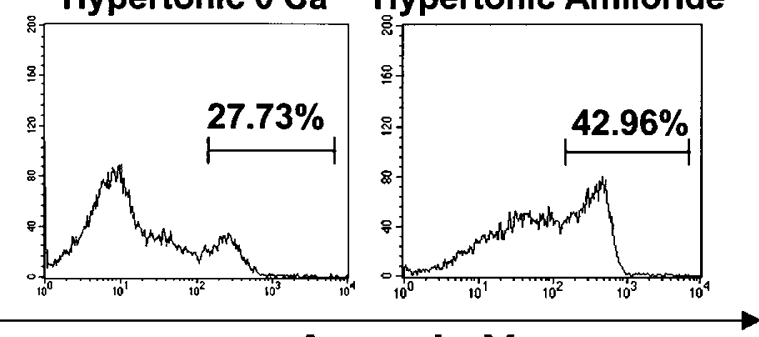

Annexin V
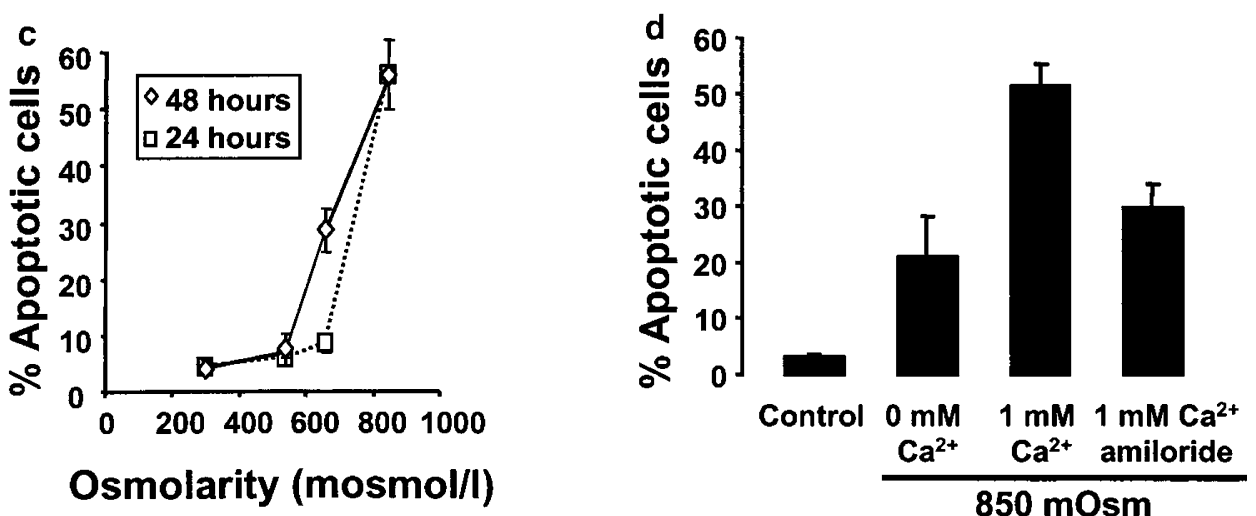

Figure 4 Erythrocyte apoptosis induced by osmotic cell shrinkage. (a) Effects of preincubation in hyperosmolar solution on cell volume with $\mathrm{Ca}^{2+}$ (upper right panel), without $\mathrm{Ca}^{2+}$ (lower left panel) and with amiloride (lower right panel) in the extracellular solution. After $24 \mathrm{~h}$ incubation cells were incubated in isotonic solution for $20 \mathrm{~min}$ and measured in the FACS calibur for forward scatter and side scatter. Geometric mean values are given for single experiments. (b) Annexin binding of erythrocytes in isotonic medium (upper left panel) and in $850 \mathrm{mOsm}$ medium after adding sucrose for $24 \mathrm{~h}$ is illustrated (upper right panel). Cells were shrunken without Ca ${ }^{2+}($ lower left panel) or with $1 \mathrm{mM} \mathrm{Ca}^{2+}$ and $1 \mathrm{mM}$ Amiloride (lower right panel). (c) Arithmetic means ( \pm S.E.M.) of annexin binding in cells at different osmolarities for $24 \mathrm{~h}$ and $48 \mathrm{~h}$. (d) Arithmetic means ( \pm S.E.M.) of annexin binding in cells exposed for $24 \mathrm{~h}$ to $850 \mathrm{mOsm}$ with or without $\mathrm{Ca}^{2+}$ or in the presence of $\mathrm{Ca}^{2+}$ with $1 \mathrm{mM}$ amiloride. Control refers to erythrocytes exposed to an isotonic buffer solution for $24 \mathrm{~h}$ 
on annexin binding was significantly blunted to $21.1 \pm 7.2 \%$ ( $n=4$, see Figure $4 \mathrm{~b}$ for a typical experiment and Figure $4 \mathrm{~d}$ for arithmetic means \pm S.E.M). Moreover, the cation channel blocker amiloride $(1 \mathrm{mM})$ decreased the number of annexin binding cells significantly to $29.8 \pm 4.0 \%(n=5$, see Figure $4 \mathrm{~b}$ for a typical experiment and Figure $4 \mathrm{~d}$ for arithmetic mean$\mathrm{s} \pm$ s.e.m.).

\section{Oxidative stress induces erythrocyte apoptosis}

Induction of oxidative stress by addition of $0.66 \mathrm{mM}$ tBOOH or $1 \mathrm{mM} \mathrm{tBOOH}$ led to marked shrinkage of erythrocytes, as reflected by a decrease of the forward scatter from $370 \pm 13$ $(n=4)$ to $314 \pm 51(n=4)$ and $167 \pm 14(n=4)$, respectively. Figure 5 a depicts typical scatter plots after oxidation of cells. In another set of experiments, we could show that treatment of erythrocytes for $15 \mathrm{~min}$ with $0.66 \mathrm{mM} \mathrm{tBOOH}$ and further incubation for $24 \mathrm{~h}$ induced significant annexin binding (Figure $5 b)$. As shown in Figure $5 \mathrm{c}, 0.66 \mathrm{mM}$ and $1 \mathrm{mM} \mathrm{tBOOH}$ increased the number of annexin binding cells from $3.2 \pm 0.5 \%$ $(n=4)$ in control cells to $26 \pm 7.5 \%(n=4)$ and $68.5 \pm 5.3 \%$ $(n=4)$, respectively. Interestingly, the oxidation-induced cell shrinkage and annexin binding were both blunted in the nominal absence of extracellular calcium (Figure 5a,b). The values for forward scatter in calcium-free incubation media approached $339 \pm 22(n=4)(0.66 \mathrm{mM} \mathrm{tBOOH})$ and $307 \pm 15$ $(n=4)(1 \mathrm{mM} \mathrm{tBOOH})$, as compared with $314 \pm 51(n=4)$ and $167 \pm 14(n=4)$ in the presence of calcium, respectively. In this line, the number of annexin-positive cells in the absence of calcium amounted to only $11.0 \pm 1.4 \% \quad(n=4) \quad(0.66 \mathrm{mM}$ $\mathrm{tBOOH})$ and $34.1 \pm 2.6 \%(n=4)(1 \mathrm{mM} \mathrm{tBOOH})$. Accordingly, removal of extracellular $\mathrm{Ca}^{2+}$ inhibited $\mathrm{tBOOH}$-induced phosphatidylserine exposure by about $66 \%$ and $53 \%$, respectively (Figure $5 \mathrm{c}$ ). Similarly, the presence of $1 \mathrm{mM}$
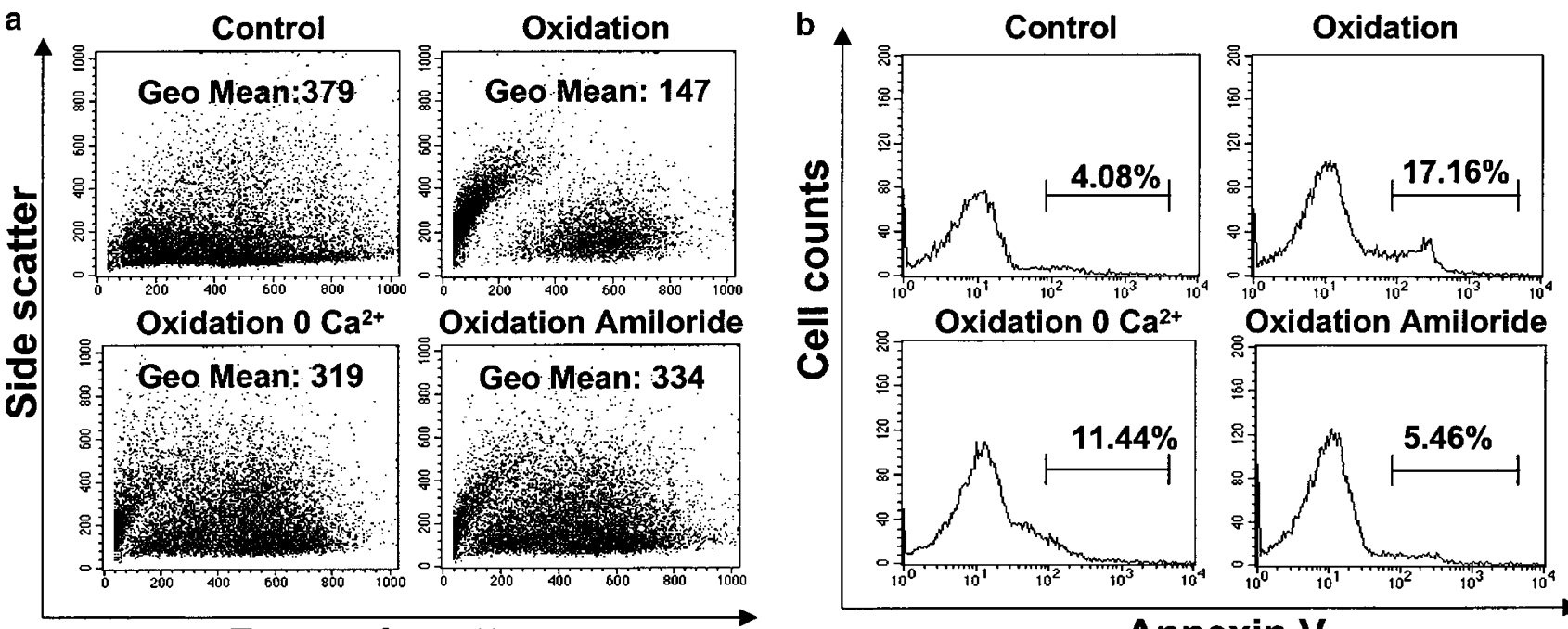

Forward scatter
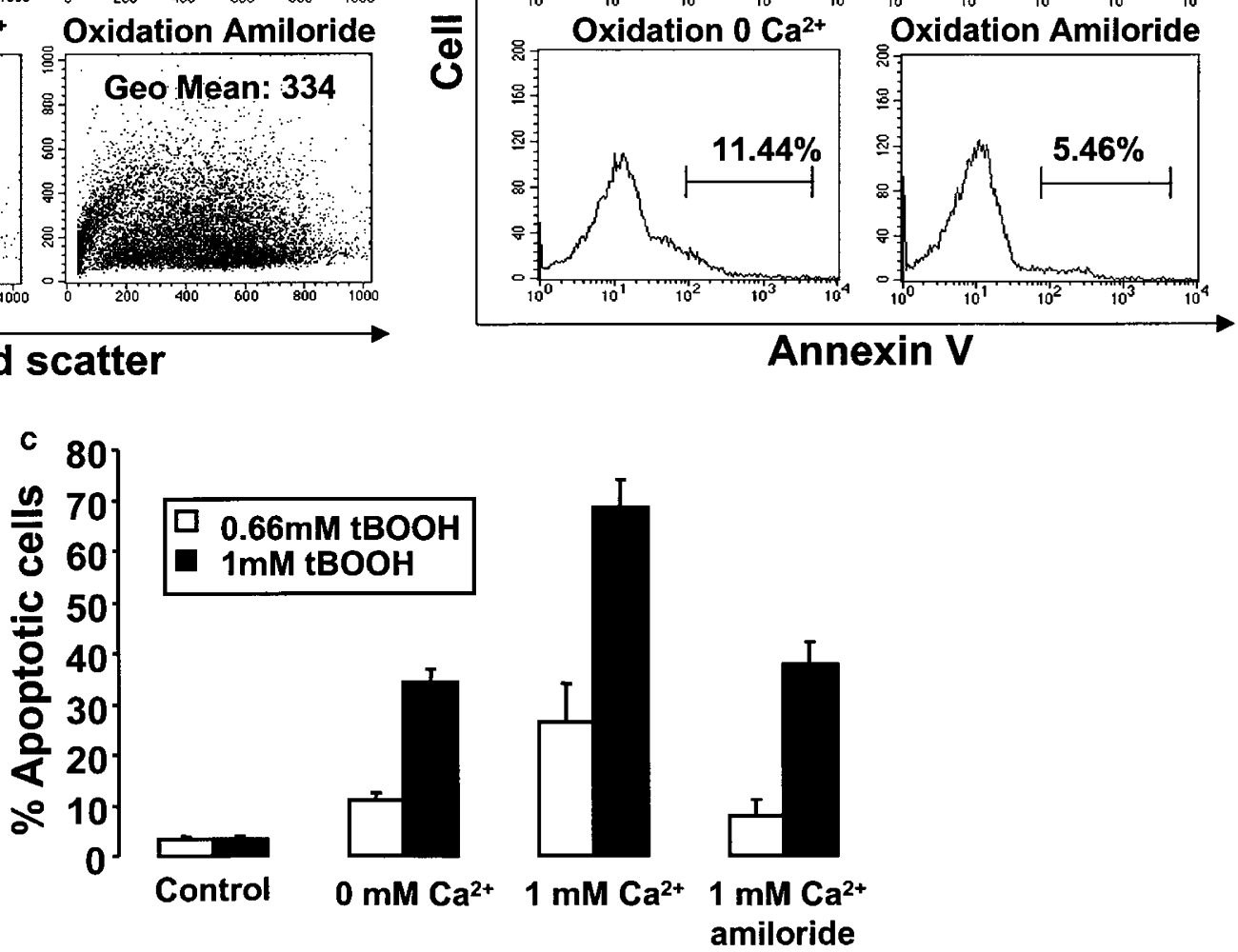

Figure 5 Erythrocyte apoptosis induced by oxidation. (a) Effects of oxidation with $1 \mathrm{mM} \mathrm{tBOOH}$ for $15 \mathrm{~min}$ and further incubation for $24 \mathrm{~h}$ on cell volume with $\mathrm{Ca}^{2+}$ (upper right panel), without $\mathrm{Ca}^{2+}$ (lower left panel) and with amiloride (lower right panel) in the extracellular solution as evidenced from forward scatter analysis. Geometric mean values are given for single experiments. (b) Effects on annexin binding without (upper left panel) and with oxidation (upper right panel) with $0.66 \mathrm{mM}$ $\mathrm{tBOOH}$ for $15 \mathrm{~min}$ and further incubation for $24 \mathrm{~h}$. Erythrocytes were oxidized in Ringer solution with $1 \mathrm{mM} \mathrm{Ca}{ }^{2+}$ (upper right panel) or without $\mathrm{Ca}^{2+}$ (lower left panel) or in the presence of $1 \mathrm{mM} \mathrm{Ca}^{2+}$ and $1 \mathrm{mM}$ amiloride (lower right panel). (c) Arithmetic means ( \pm S.E.M.) of annexin binding in cells after exposure to $1 \mathrm{mM}$ tBOOH or $0.66 \mathrm{mM}$ tBOOH for $15 \mathrm{~min}$ and further incubation for $24 \mathrm{~h}$, either in the presence or in the absence of $1 \mathrm{mM} \mathrm{Ca} \mathrm{Ca}^{2+}$ or in the presence of $1 \mathrm{mM} \mathrm{Ca} \mathrm{C}^{2+}$ with $1 \mathrm{mM}$ amiloride are given. Control refers to erythrocytes exposed to oxidant free buffer solution for $24 \mathrm{~h}$ 
amiloride blunted the effect of $\mathrm{tBOOH}$ on cell volume (Figure $5 \mathrm{a})$ and annexin binding (Figure $5 \mathrm{~b}$ ) even in the presence of $1 \mathrm{mM} \mathrm{Ca}{ }^{2+}$. The respective values of forward scatter amounted to $356 \pm 24.0 \quad(n=4) \quad(0.66 \mathrm{mM} \mathrm{tBOOH})$ and $291 \pm 27(n=4)(1 \mathrm{mM} \mathrm{tBOOH})$. In the presence of $1 \mathrm{mM}$ amiloride, annexin-positive cells were reduced to $7.9 \pm 3.2 \%$ $(0.66 \mathrm{mM} \mathrm{tBOOH})$ and $37.7 \pm 4.4 \%(1 \mathrm{mM} \mathrm{tBOOH})$, which reflects an inhibition of $\mathrm{tBOOH}$-induced annexin binding by 80 and $48 \%$, respectively (Figure $5 \mathrm{c}$ ).

\section{Glucose depletion induces erythrocyte apoptosis}

As antioxidative defence requires energy and thus depends on glucose supply to erythrocytes, ${ }^{13,14}$ the effect of glucose removal has been tested (see Figure 6a for individual experiments). In the presence of glucose, $3.1 \pm 0.6 \%(n=4)$ of the erythrocytes bound annexin. Exposure to glucose-free medium increased the number of annexin binding cells to $11.2 \pm 2.2 \%(n=4)$ after $24 \mathrm{~h}$ and to $49.4 \pm 5.7 \%(n=4)$ after $48 \mathrm{~h}$ (Figure $6 \mathrm{~b}$ ). The increase of annexin binding was significantly blunted in the nominal absence of calcium. The respective values were $10.4 \pm 2.5 \%(n=4)$ after $24 \mathrm{~h}$ and $10.0 \pm 1.9 \%(n=4)$ after $48 \mathrm{~h}$. Similarly, the effect of glucose depletion was inhibited in the presence of $1 \mathrm{mM}$ amiloride. The respective values were $5.7 \pm 1.8 \%(n=4)$ after $24 \mathrm{~h}$ and $11.7 \pm 1.9 \%(n=4)$ after $48 \mathrm{~h}$ (Figure $6 \mathrm{~b})$.

\section{lonomycin, osmotic shock, oxidative stress and glucose depletion all decrease erythrocyte number}

The number of erythrocytes was significantly decreased by an exposure to $1 \mu \mathrm{M}$ ionomycin for $16 \mathrm{~h}$, by a $24 \mathrm{~h}$ exposure to $850 \mathrm{mOsm}$, by a $15 \mathrm{~min}$ exposure to $1 \mathrm{mM}$ tBOOH and further incubation for $24 \mathrm{~h}$ in oxidant-free buffer and by a $48 \mathrm{~h}$ exposure to glucose-free buffer. In the absence of extracellular $\mathrm{Ca}^{2+}$, the decline of cell number was significantly blunted (Figure 7) thereby confirming the results of the annexin-binding assay.

\section{Discussion}

The present study demonstrates that oxidative and osmotic stresses, well-known triggers of apoptotic death of nucleated cells, ${ }^{3,10,12}$ are similarly powerful stimuli of erythrocyte apoptosis. Even though erythrocytes lack nuclei and mitochondria, they are capable of undergoing some of the morphological features of apoptosis, such as external exposure of phosphatidylserine, membrane blebbing and cell shrinkage. ${ }^{1}$ All these events are triggered by increase of cytosolic calcium activity, ${ }^{4,5}$ while erythrocytes are resistant to serum deprivation and staurosporine, known triggers of apoptosis in nucleated cells. ${ }^{1}$

The present paper further provides evidence for the involvement of amiloride sensitive, cell volume regulated cation channels in the induction of apoptotic cell death by both osmotic cell shrinkage and oxidative stress. The channels have previously been characterized and shown to be inhibited by amiloride. ${ }^{15,16}$ Both, osmotic and oxidative stresses open the channel. The effect of both osmotic and oxidative stress is
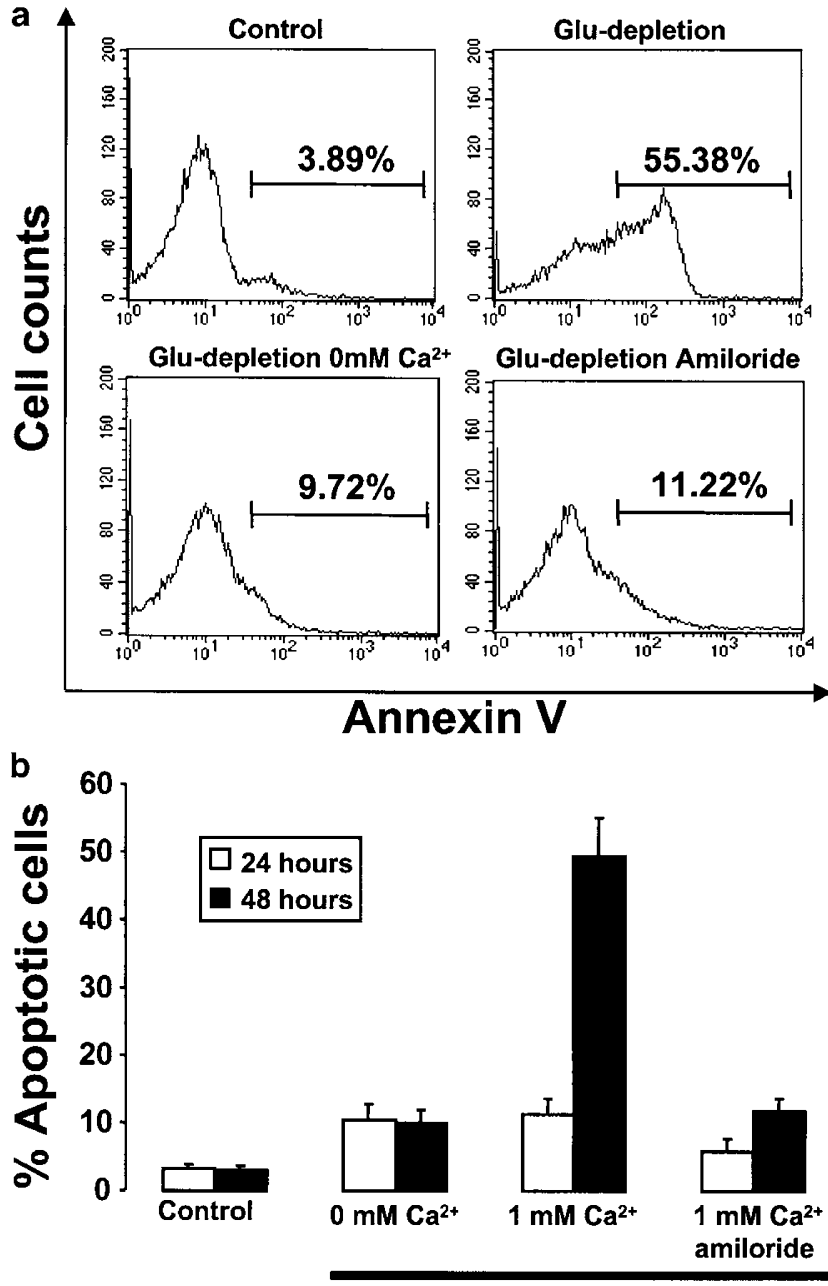

Glucose-depletion

Figure 6 Erythrocyte apoptosis induced by glucose depletion. (a) Annexin binding of erythrocytes after $48 \mathrm{~h}$ of incubation in the presence (upper left panel) or in the absence of glucose (upper right panel). Cells were additionally incubated in the absence of glucose either without $\mathrm{Ca}^{2+}$ (lower left panel) or with $1 \mathrm{mM} \mathrm{Ca}^{2+}$ and $1 \mathrm{mM}$ amiloride (lower right panel). (b) Arithmetic means ( \pm S.E.M.) of annexin binding in cells incubated for $24 \mathrm{~h}$ and $48 \mathrm{~h}$ in the absence of glucose, either with or without $\mathrm{Ca}^{2+}$ depletion or in the presence of $1 \mathrm{mM} \mathrm{Ca}^{2+}$ with $1 \mathrm{mM}$ amiloride. Control refers to cells incubated in the presence of glucose and $\mathrm{Ca}^{2+}$ for $24 \mathrm{~h}$ and $48 \mathrm{~h}$

mimicked by the addition of the $\mathrm{Ca}^{2+}$ ionophore iomomycin in the presence, but not the absence of extracellular $\mathrm{Ca}^{2+}$. Moreover, amiloride and decrease of extracellular $\mathrm{Ca}^{2+}$ blunt the effects of osmotic and oxidative stress on annexin binding. Thus, it appears safe to conclude that osmotic and oxidative stresses trigger erythrocyte apoptosis at least in part by stimulating the cation channel and thus increasing cytosolic $\mathrm{Ca}^{2+}$ activity.

Similar to osmotic stress, oxidative stress leads to marked erythrocyte shrinkage, an effect probably resulting from activation of the $\mathrm{Ca}^{2+}$-sensitive $\mathrm{K}^{+}$channel in the erythrocyte cell membrane, which leads to hyperpolarization of the cell membrane and subsequent erythrocyte loss of $\mathrm{KCl} .^{17-19}$

The mechanisms described here could well participate in the limitation of erythrocyte survival. The phosphatidylserine 


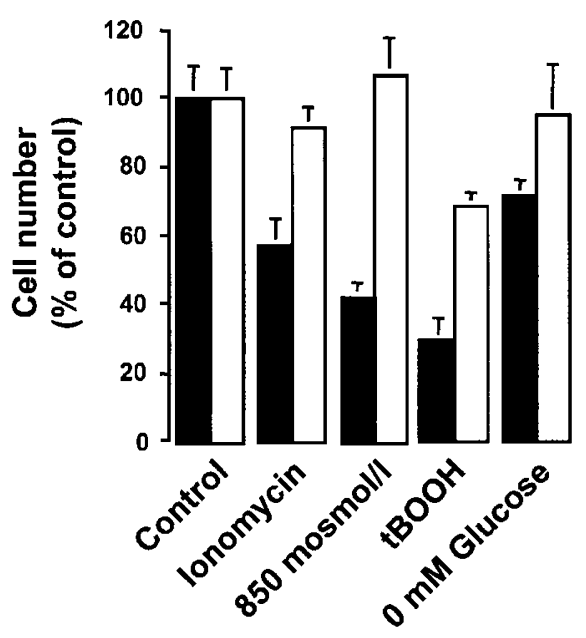

Figure 7 Decrease of erythrocyte number by exposure to ionomycin, osmotic shock, oxidative stress and glucose depletion. Arithmetic means \pm S.E.M. $(n=3)$ of erythrocyte number in \% of control following exposure to ionomycin $(1 \mu \mathrm{M})$ for $16 \mathrm{~h}$, to hyperosmolarity of $850 \mathrm{mOsm}$ for $24 \mathrm{~h}$, to $\mathrm{tBOOH}(1 \mathrm{mM})$ for $15 \mathrm{~min}$ and subsequent incubation for $24 \mathrm{~h}$ or to glucose-free buffer for $48 \mathrm{~h}$, in the presence (closed bars) or absence (open bars) of $1 \mathrm{mM} \mathrm{Ca}^{2+}$. Erythrocyte numbers under control conditions in the presence and absence of $\mathrm{Ca}^{2+}$ were $(1.7 \pm 0.3) \times 10^{8} \mathrm{cells} / \mathrm{ml}$ and $(1.6 \pm 0.16) \times 10^{8}$ cells $/ \mathrm{ml}$, respectively

exposure at the cell surface is thought to stimulate the uptake by macrophages. ${ }^{20,21}$ Thus, to the extent that calcium triggers the breakdown of phosphatidylserine asymmetry, an increase of cytosolic $\mathrm{Ca}^{2+}$ activity is expected to trigger the clearance of the affected erythrocytes. ${ }^{1}$ This may be important for erythrocyte ageing, which is paralleled by increase of cytosolic $\mathrm{Ca}^{2+}$ activity. ${ }^{21,22}$ Moreover, according to the present results, oxidative stress or defects of antioxidative defence ${ }^{23}$ clearly enhance $\mathrm{Ca}^{2+}$ entry via the cation channels. This leads to higher intracellular $\mathrm{Ca}^{2+}$ concentrations and thus accelerates erythrocyte apoptosis and clearance. During passage of the renal medulla, erythrocytes are exposed to excessive osmolarities sufficient to activate the cation channel. Normally, the exposure is too short, though, to trigger apoptosis. Nevertheless, it is noteworthy that during acute renal failure erythrocytes may be trapped in renal medulla. ${ }^{24}$ The subsequent erythrocyte apoptosis may then contribute to the derangement of microcirculation. Beyond this any erythrocyte disorder facilitating erythrocyte shrinkage, such as sickle cell disease, ${ }^{8,25}$ thalassemia ${ }^{26}$ or iron deficiency, ${ }^{27}$ could, to the extent as it leads to activation of the cell volume regulatory cation channels, trigger premature apoptosis and thus accelerate erythrocyte death.

The volume regulatory cation channels are not only expressed in erythrocytes but in several nucleated cells. ${ }^{28-34}$ As an increase of cytosolic $\mathrm{Ca}^{2+}$ could similarly induce apoptotic cell death in nucleated cells, ${ }^{2}$ activation of the volume regulated cation channels could similarly participate in the triggering of apoptosis in nucleated cells exposed to an osmotic shock. $^{3,9-12}$

In summary, we conclude from our results that erythrocyte apoptosis can be induced by different stimuli, such as osmotic shock or oxidative stress, an effect at least partially due to activation of calcium-permeable cation channels. The present data thus disclose a physiological mechanism that may indeed be relevant for the half-life and the turnover of this highly specialised cell type.

\section{Materials and Methods}

\section{Solutions}

Erythrocytes were drawn from healthy volunteers. Erythrocytes were either used without purification or after separation by centrifugation for $25 \mathrm{~min} ; 2000 \mathrm{~g}$ over Ficoll (Biochrom KG, Berlin, Germany). Experiments with nonpurified or experiments with Ficoll-separated erythrocytes yielded the same results (data not shown). Experiments were performed at $37^{\circ} \mathrm{C}$ in Ringer solution containing (in $\mathrm{mM}$ ) $125 \mathrm{NaCl}, 5 \mathrm{KCl}, 1 \mathrm{MgSO}_{4}, 32 \mathrm{~N}-2-$ hydroxyethylpiperazine- $\mathrm{N}$-2-ethanesulfonic acid (HEPES), 5 glucose, 1 $\mathrm{CaCl}_{2} ; \mathrm{pH}$ 7.4. For the nominally calcium-free solution $\mathrm{CaCl}_{2}$ was replaced by $1 \mathrm{mM}$ ethylene glycol-bis ( $\beta$-aminoethyl ether)- $N, N, N^{\prime}, N^{\prime}$-tetraacetic acid (EGTA). Osmolarity was increased to $850 \mathrm{mM}$ by adding sucrose. Ionomycin was used at a concentration of $1 \mu \mathrm{M}$, amiloride at a concentration of $1 \mathrm{mM}$. The final concentration of the solvent dimethyl sulfoxide DMSO was in both cases $0.1 \%$. Ionomycin, amiloride and leupeptin were purchased from Sigma (Taufkirchen, Germany). ${ }^{45} \mathrm{Ca}^{2+}$ was from ICN Biomedicals GmbH (Eschwege, Germany) and delivered as $\mathrm{CaCl}_{2}$ in aqueous solution (specific activity: $0.185-1.11 \mathrm{TBq} / \mathrm{g} \mathrm{Ca}$ ).

\section{Patch clamp}

Patch-clamp experiments were performed according to Hamill et al. ${ }^{35}$ RBCs were recorded at $35^{\circ} \mathrm{C}$. A continuous superfusion was applied through a flow system inserted into the dish. The bath was grounded via a $2 \%$ agarose bridge filled with pipette solution (see below). Borosilicate glass pipettes ( $9 \mathrm{M} \Omega$ tip resistance; GC 150 TF-10, Clark Medical Instruments, Pangbourne, UK) manufactured by a microprocessor-driven DMZ puller (Zeitz, Augsburg, Germany) were used in combination with an MS314 electrical micromanipulator (MW, Märzhäuser, Wetzlar, Germany). The currents were recorded in voltage-clamp mode in fast-whole-cell, inside-out and outside-out configuration, respectively, by an EPC-9 amplifier (Heka, Lambrecht, Germany) using Pulse software (Heka) and an ITC-16 Interface (Instrutech, Port Washington, NY, USA). The wholecell currents were evoked by a pulse protocol, clamping the voltage in 11 successive $400-\mathrm{ms}$ square pulses from the $-10 \mathrm{mV}$ holding potential to potentials between $-100 \mathrm{mV}$ and $+100 \mathrm{mV}$.

Whole-cell currents were recorded first in standard isotonic bath solution [containing in mM: $115 \mathrm{NaCl}, 10 \mathrm{HEPES}, 5 \mathrm{KCl}, 5 \mathrm{CaCl}_{2}, 10$ $\mathrm{MgCl}_{2}$, titrated with $\mathrm{NaOH}$ to $\left.\mathrm{pH} 7.4\right]$ in combination with a pipette solution containing (in mM): $60 \mathrm{~K}$-D-gluconate, $80 \mathrm{KCl}$, EGTA, $1 \mathrm{MgCl}_{2}, 1 \mathrm{Mg}$-ATP, and $10 \mathrm{HEPES}$, titrated to $\mathrm{pH} 7.2$ with $\mathrm{KOH}$. The whole-cell currents were further recorded during cell shrinkage after addition of $400 \mathrm{mM}$ sucrose to the bath and after replacement of $\mathrm{Na}^{+}$in the bath by the impermeable cation $\mathrm{NMDG}^{+}$.

In a further series of whole-cell experiments, a pipette solution containing (in mM) $120 \mathrm{NaCl}, 5 \mathrm{HEPES} / \mathrm{NaOH}, 1$ EGTA, $1 \mathrm{Mg}-\mathrm{ATP} ; \mathrm{pH}$ 7.2 was combined with the standard $\mathrm{NaCl}$ bath solution. Currents were measured at room temperature before and during oxidative stress applied by adding $1 \mathrm{mM} \mathrm{tBOOH}$ to the bath solution.

Excised patch, inside out and outside-out recordings were obtained with a pipette solution containing (in $\mathrm{mM}$ ) $133 \mathrm{KCl}, 3 \mathrm{EGTA}, 1.78 \mathrm{MgCl}_{2}, 1.13$ $\mathrm{CaCl}_{2}, 1 \mathrm{~K}_{2} \mathrm{ATP}$, and $10 \mathrm{HEPES}$, titrated to $\mathrm{pH} 7.2$ with $\mathrm{KOH}$ combined with standard isotonic $\mathrm{NaCl}$ bath solution. Currents through the excised 
patches were characterized by replacing $\mathrm{NaCl}$ in the bath by equiosmolar amounts of Na-gluconate, NMDG-gluconate, and Ca-(gluconate) $)_{2}$ or by applying amiloride ( $1 \mathrm{mM})$ to the bath solution.

The offset potentials between both electrodes were zeroed before sealing. The potentials were corrected for liquid junction potentials as estimated according to Barry and Lynch. ${ }^{36}$ The original whole-cell current traces are depicted after $500 \mathrm{~Hz}$ low-pass filtering and currents of the individual voltage square pulses are superimposed. The applied voltages refer to the cytoplasmic face of the membrane with respect to the extracellular space. The inward currents, defined as flow of positive charge from the extracellular to the cytoplasmic membrane face, are negative currents and depicted as downward deflections of the original current traces.

\section{Measurement of calcium uptake}

Calcium uptake was measured as described in detail elsewhere. ${ }^{37,38}$ Erythrocytes were washed four times by centrifugation $(2000 \times g$ for $5 \mathrm{~min}$ ) and resuspended in five volumes of solution A containing in $\mathrm{mM}: 80$ $\mathrm{KCl}, 70 \mathrm{NaCl}, 10 \mathrm{HEPES}, 0.2 \mathrm{MgCl}_{2}, 0.1 \mathrm{EGTA} ; \mathrm{pH} 7.5$ to remove extracellular $\mathrm{Ca}^{2+}$. The cell pellet was then washed twice in solution $\mathrm{B}$ to remove EGTA from the medium. Solution $B$ had the same composition as solution A, but without EGTA. The cells were suspended at $10 \%$ haematocrit and preincubated for $20 \mathrm{~min}$ at $37^{\circ} \mathrm{C}$ in the final incubation solution B supplemented with $10 \mathrm{mM}$ inosine and $1 \mathrm{mM}$ sodium orthovanadate. Then ${ }^{45} \mathrm{Ca}^{2+}$ was added from a $100 \mathrm{mM} \mathrm{CaCl}_{2}$ stock solution with a specific activity of about $10^{7} \mathrm{cpm} \mu \mathrm{mol}$ to reach an end concentration of $150 \mu \mathrm{M}$. After different times, $100 \mu \mathrm{l}$ aliquots were delivered into $1.2 \mathrm{ml}$ of ice-cold solution $B$ with $0.2 \mathrm{mM} \mathrm{CoCl}_{2}$ and $1 \mathrm{mM}$ amiloride. The cells were collected by centrifugation in an Eppendorf centrifuge ( $14000 \mathrm{rpm}$ for $0.5 \mathrm{~min}, 4^{\circ} \mathrm{C}$ ) and the cell pellet was washed twice using $1 \mathrm{ml}$ of the same medium. The supernatant was discarded and the cells were lysed and the proteins precipitated by addition of $0.6 \mathrm{ml} 6 \%$ trichloroacetic acid (TCA). After a further spin (14000 rpm for $2 \mathrm{~min}, 4^{\circ} \mathrm{C}$ ), $0.5 \mathrm{ml}$ of clear supernatant was used for measuring ${ }^{45} \mathrm{Ca}^{2+}$ radioactivity by scintillation counting. ${ }^{45} \mathrm{Ca}^{2+}$-specific activity was determined by addition of $0.6 \mathrm{ml} 6 \%$ TCA to $100 \mu \mathrm{l}$ suspension samples and centrifugation as described above. Then, $100 \mu \mathrm{l}$ of clear supernatant were taken for scintillation counting. The total calcium content of the cells $\left[\mathrm{Ca}_{\mathrm{T}}\right]_{\mathrm{i}}$ was calculated by dividing the activity of the samples by the specific activity of ${ }^{45} \mathrm{Ca}^{2+}$ and by the number of cells.

Ionomycin $(1 \mu \mathrm{M})$ and $1 \mathrm{mM} \mathrm{tBOOH}$ were added to the cell suspensions together with ${ }^{45} \mathrm{Ca}^{2+}$. Exposure of erythrocytes to $850 \mathrm{mOsm}$ was achieved by addition of sucrose to solution B during $20 \mathrm{~min}$ of preincubation and $10 \mathrm{~min}$ of ${ }^{45} \mathrm{Ca}^{2+}$ uptake. Note that the delivery medium for washing the cells after radioactive labelling was also adjusted to $850 \mathrm{mOsml} / \mathrm{l}$ by addition of sucrose. Glucose depletion was achieved by preincubating the cells in Ringer solution (5\% haematocrit) for 24 and $48 \mathrm{~h}$ at $37^{\circ} \mathrm{C}$ in the absence of glucose. Control cells were preincubated in the presence of $5 \mathrm{mM}$ glucose.

\section{FACS analysis}

FACS analysis was performed essentially as described. ${ }^{39}$ After incubation, cells were washed in annexin-binding buffer containing (in $\mathrm{mM}$ ) $125 \mathrm{NaCl}$, 10 HEPES, pH 7.4, and $5 \mathrm{CaCl}_{2}$. Erythrocytes were stained with AnnexinFlous (Böhringer Mannheim, Germany) at a 1: 100 dilution. After $15 \mathrm{~min}$, samples were diluted 1: 5 and measured by flow cytometric analysis (FACS-Calibur from Becton Dickinson). Cells were analysed by forward and sideward scatter and annexin-fluorescence intensity was measured in FL-1.

\section{Determination of cell numbers}

Erythrocytes were suspended at $2 \%$ haematocrit and incubated under different control and stress conditions ( $1 \mu \mathrm{M}$ ionomycin, osmotic and oxidative stress, glucose depletion). After incubation, the cell number was determined using a hemocytometer as described previously. ${ }^{40}$

\section{Statistics}

Data are expressed as arithmetic means \pm S.E.M. and statistical analysis was made by paired or unpaired $t$-test, where appropriate.

\section{Acknowledgments}

The authors acknowledge the technical assistance of $E$ Faber and the meticulous preparation of the manuscript by $T$ Loch. This study was supported by the Deutsche Forschungsgemeinschaft, Nr. La 315/4-3 and La 315/6-1, the Bundesministerium für Bildung, Wissenschaft, Forschung und Technologie (Center for Interdisciplinary Clinical Research) $01 \mathrm{KS}$ 9602 and the Biomed program of the EU (BMH4-CT96-0602), and a A.V. Humboldt stipendium to C.D.

\section{References}

1. Daugas $E$, Cande $C$ and Kroemer G (2001) Erythrocytes: death of a mummy. Cell Death Differ. 8: 1131-1133

2. Green DR and Reed JC (1998) Mitochondria and apoptosis. Science 281: 1309-1312

3. Gulbins E, Jekle A, Ferlinz K, Grassme H and Lang F (2000) Physiology of apoptosis. Am. J. Physiol. Renal Physiol. 279: 605-615

4. Berg CP, Engels IH, Rothbart A, Lauber K, Renz A, Schlosser SF, SchulzeOsthoff $K$ and Wesselborg $S$ (2001) Human mature red blood cells express caspase-3 and caspase-8, but are devoid of mitochondrial regulators of apoptosis. Cell Death Differ. 8: 1197-1206

5. Bratosin D, Estaquier J, Petit F, Arnoult D, Quatannens B, Tissier JP, Slomianny C, Sartiaux C, Alonso C, Huart JJ, Montreuil J and Ameisen JC (2001) Programmed cell death in mature erythrocytes: a model for investigating death effector pathways operating in the absence of mitochondria. Cell Death Differ. 8: 1143-1156

6. Bortner CD and Cidlowski JA (1998) A necessary role for cell shrinkage in apoptosis. Biochem. Pharmacol. 56: 1549-1559

7. Bortner CD and Cidlowski JA (1999) Caspase independent/dependent regulation of $\mathrm{K}(+)$, cell shrinkage, and mitochondrial membrane potential during lymphocyte apoptosis. J. Biol. Chem. 274: 21953-21962

8. Lang F, Busch GL, Ritter M, VolkI H, Waldegger S, Gulbins E and Haussinger D (1998) Functional significance of cell volume regulatory mechanisms. Physiol. Rev. 78: 247-306

9. Maeno E, Ishizaki Y, Kanaseki T, Hazama A and Okada Y (2000) Normotonic cell shrinkage because of disordered volume regulation is an early prerequisite to apoptosis. Proc. Natl. Acad. Sci. USA 97: 9487-9492

10. Michea L, Ferguson DR, Peters EM, Andrews PM, Kirby MR and Burg MB (2000) Cell cycle delay and apoptosis are induced by high salt and urea in renal medullary cells. Am. J. Physiol. Renal Physiol. 278: 209-218

11. Roger F, Martin PY, Rousselot M, Favre H and Feraille E (1999) Cell shrinkage triggers the activation of mitogen-activated protein kinases by hypertonicity in the rat kidney medullary thick ascending limb of the Henle's loop. Requirement of p38 kinase for the regulatory volume increase response. J. Biol. Chem. 274: 34103-34110

12. Rosette $C$ and Karin $M$ (1996) Ultraviolet light and osmotic stress: activation of the JNK cascade through multiple growth factor and cytokine receptors. Science 274: 1194-1197

13. Lachant NA and Zerez CR (1988) Inhibitory effect of mannose on erythrocyte defense against oxidants. Biochim. Biophys. Acta. 964: 96-104 
14. Bashan N, Makover O, Livne A and Moses S (1980) Effect of oxidant agents on normal and G6PD-deficient erythrocytes. Isr. J. Med. Sci. 16: 351-356

15. Duranton C, Huber SM and Lang $F(2002)$ Oxidation induces a $\mathrm{Cl}(-)$ dependent cation conductance in human red blood cells. J. Physiol. 539: 847-855

16. Huber SM, Gamper N and Lang F (2001) Chloride conductance and volumeregulatory nonselective cation conductance in human red blood cell ghosts. Pflugers Arch. 441: 551-558

17. Bookchin RM, Ortiz OE and Lew VL (1987) Activation of calcium-dependent potassium channels in deoxygenated sickled red cells. Prog. Clin. Biol. Res. 240: $193-200$

18. Brugnara C, de Franceschi $L$ and Alper SL (1993) Inhibition of $\mathrm{Ca}(2+)$ dependent $\mathrm{K}+$ transport and cell dehydration in sickle erythrocytes by clotrimazole and other imidazole derivatives. J. Clin. Invest. 92: 520-526

19. Franco RS, Palascak M, Thompson H, Rucknagel DL and Joiner CH (1996) Dehydration of transferrin receptor-positive sickle reticulocytes during continuous or cyclic deoxygenation: role of $\mathrm{KCl}$ cotransport and extracellular calcium. Blood 88: 4359-4365

20. Boas FE, Forman $L$ and Beutler $E$ (1998) Phosphatidylserine exposure and red cell viability in red cell aging and in hemolytic anemia. Proc. Natl. Acad. Sci. USA 95: 3077-3081

21. Romero PJ and Romero EA (1999) Effect of cell ageing on Ca2+ influx into human red cells. Cell Calcium 26: 131-137

22. Kiefer CR and Snyder LM (2000) Oxidation and erythrocyte senescence. Curr. Opin. Hematol. 7: 113-116

23. Damonte G, Guida L, Sdraffa A, Benatti U, Melloni E, Forteleoni G, Meloni T, Carafoli $E$ and De Flora A (1992) Mechanisms of perturbation of erythrocyte calcium homeostasis in favism. Cell Calcium 13: 649-658

24. Mason J (1986) The pathophysiology of ischaemic acute renal failure. A new hypothesis about the initiation phase. Ren. Physiol. 9: 129-147

25. Joiner CH (1993) Cation transport and volume regulation in sickle red blood cells. Am. J. Physiol. 264: 251-270

26. Mach-Pascual S, Darbellay R, Pilotto PA and Beris $P$ (1996) Investigation of microcytosis: a comprehensive approach. Eur. J. Haematol. 57: 54-61

27. Jolobe OM (2000) Prevalence of hypochromia (without microcytosis) vs microcytosis (without hypochromia) in iron deficiency. Clin. Lab. Haematol. 22 79-80
28. Cabado AG, Vieytes MR and Botana LM (1994) Effect of ion composition on the changes in membrane potential induced with several stimuli in rat mast cells. J. Cell Physiol. 158: 309-316

29. Chan HC, Goldstein J and Nelson DJ (1992) Alternate pathways for chloride conductance activation in normal and cystic fibrosis airway epithelial cells. Am. J. Physiol. 262: 1273-1283

30. Gamper N, Huber SM, Badawi K and Lang F (2000) Cell volume-sensitive sodium channels upregulated by glucocorticoids in U937 macrophages. Pflugers Arch. 441: 281-286

31. Koch J and Korbmacher C (1999) Osmotic shrinkage activates nonselective cation (NSC) channels in various cell types. J. Membr. Biol. 168: 131-139

32. Volk T, Fromter E and Korbmacher C (1995) Hypertonicity activates nonselective cation channels in mouse cortical collecting duct cells. Proc. Natl. Acad. Sci. USA 92: 8478-8482

33. Wehner $\mathrm{F}$, Sauer $\mathrm{H}$ and Kinne RK (1995) Hypertonic stress increases the $\mathrm{Na}+$ conductance of rat hepatocytes in primary culture. J. Gen. Physiol. 105: 507535

34. Wehner F, Bohmer C, Heinzinger H, van den Boom F and Tinel H (2000) The hypertonicity-induced $\mathrm{Na}(+)$ conductance of rat hepatocytes: physiological significance and molecular correlate. Cell Physiol. Biochem. 10: 335-340

35. Hamill OP, Marty A, Neher E, Sakmann B and Sigworth FJ (1981) Improved patch-clamp techniques for high-resolution current recording from cells and cell-free membrane patches. Pflugers Arch. 391: 85-100

36. Barry PH and Lynch JW (1991) Liquid junction potentials and small cell effects in patch-clamp analysis. J. Membr. Biol. 121: 101-117

37. Tiffert T and Lew VL (1997) Cytoplasmic calcium buffers in intact human red cells. J. Physiol. 500: 139-154

38. Tiffert T, Staines HM, Ellory JC and Lew VL (2000) Functional state of the plasma membrane $\mathrm{Ca}^{2+}$ pump in Plasmodium falciparum-infected human red blood cells. J. Physiol. 525: 125-134

39. Andree HA, Reutelingsperger CP, Hauptmann R, Hemker HC, Hermens WT and Willems GM (1990) Binding of vascular anticoagulant alpha (VAC alpha) to planar phospholipid bilayers. J. Biol. Chem. 265: 4923-4928

40. Wieder T, Perlitz C, Wieprecht M, Huang RT, Geilen CC and Orfanos CE (1995) Two new sphingomyelin analogues inhibit phosphatidylcholine biosynthesis by decreasing membrane-bound CTP: phosphocholine cytidylyltransferase levels in HaCaT cells. Biochem J. 311: 873-879 